\title{
SEM1 wt Allele
}

National Cancer Institute

\section{Source}

National Cancer Institute. SEM1 wt Allele. NCI Thesaurus. Code C52268.

Human SEM1 wild-type allele is located in the vicinity of $7 q 21.3$ and is approximately 228 $\mathrm{kb}$ in length. This allele, which encodes 26 proteasome complex subunit SEM1 protein, is involved in the mediation of protein degradation. The gene may play a role in split hand/split foot malformation. 